\title{
Transparency of Village Fund Management
}

\author{
Herman H, Ilham \\ Public Administration, Universitas Negeri Makassar, Makassar, Indonesia \\ Email: hermandody@unm.ac.id; Ilham.nhoshashi@gmail.com
}

(Received: January-2021; Reviewed: February-2021; Accepted: March-2021;

Avalaible Online: March-2021; Published: March-2021)

\begin{abstract}
Transparency of Village Fund Management in Sunggumanai Village, Gowa Regency. Thesis. Public Administration Study Program. Postgraduate Program. Makassar State University. This study aims to find out and describe the Transparency of Village Fund Management in Sunggumanai Village, Gowa Regency. This research method uses a Qualitative approach with data collection techniques using interactive models, namely data collection, data condensation, data presentation, and conclusion verification. The results showed that 1). The availability of adequate information about village funds is considered effective. 2). The knowledge and insights of the community about village funds are considered to have been carried out effectively. 3). Increasing public trust in the management of village funds is considered to have been running effectively. 4). Increasing community participation in village fund activities is considered effective. Overall, it can be understood that the Transparency of Village Fund Management in Sunggumanai Village, Gowa Regency, has been effectively achieved by openness in the preparation of village fund programs, availability of information access through village forums, billboards, and the inscription making of every completed project development. So that the response of Sunggumanai villagers to the implementation of village government is going well, allocating in the performance of village funding programs has increased public confidence in the village government, the result of village development is increasingly advanced. Creating a good relationship between the community and the government through community empowerment with a labor-intensive model of the local village community is allowed to implement village funding programs both in physical and nonphysical development.
\end{abstract}

Keywords: Transparency; village funds; Management

\section{INTRODUCTION}

The village is the smallest part of a province. Administratively, the village consists of more than one hamlet combined into a stand-alone area and has the right to regulate its household (autonomy) (Isma et al., 2017; Niswaty et al., 2020; Saggaf et al., 2014; Salam, 
2015). the majority of the people still hold fast to the customs that have existed since hereditary and live in cooperation with each other.

The village as the smallest system of government demands a better reform and aspects of village development that must be improved and the level of human life away from poverty (Daraba et al., 2018; Kahar et al., 2019). Various problems in the village are very complex. Village development should reflect mutual attitude and togetherness as a form of precepts in Pancasila to realize a fair and prosperous village community. The implementation of village development must be under what has been planned in the planning process, and the community has the right to know and conduct supervision on village development (Handoyo, 2012; Inskeep, 1991; Marcellus, 2009; Nugroho et al., 2021).

In Law No. 6 of 2014 concerning Villages, it is stated that the village is a unitary legal community that has territorial boundaries authorized to regulate and manage government affairs, the interests of local communities based on community initiatives, rights of origin, and/or traditional rights recognized and respected in the system of government of the Unitary State of the Republic of Indonesia.

In law number 6 of 2014 on villages has regulated the village's finances and assets to provide services to the community, which are sourced from the original income of the region. There is an obligation for the government from the center to the district or city to provide funds transfer for villages, grants, or donations.

One form of transfer from the government to support village development is the Village Fund (DD). Village Fund is a fund sourced from the State Budget (APBN) intended for villages transferred through the District Budget (APBD) district/city to finance the implementation of government, implementation of development, community development, and community empowerment.

Direct assistance of Village Fund (DD) is a grant allocated to the village government is used to improve institutional community service facilities and village infrastructure needed or prioritized by the community, whose income and management administration is carried out and accounted for by the village head.

The use of Village Funds (DD) is prone to misappropriation of funds by parties that the community should trust in building villages to be more advanced and developed. This is the importance of the role of the community as a direct supervisor and cannot be separated from the role of the district government as a funder always to monitor the development in the village. Management and implementation of village government activities need to be an aspect of good governance.

The main principles of good governance are community participation, the establishment of legal supremacy, the growth of transparency and accountability built based on free flow of information and information needs to be accessible to interested and adequate parties, caring for stakeholders, oriented to equality of effectiveness and efficiency, and the existence of a strategic vision.

This needs to be done because $70 \%$ of the allocation of funds is allocated for community empowerment and $30 \%$ for the implementation of village government. Village funds used for the empowerment of village communities are directed to the improvement or development of village physical facilities and infrastructure, which includes the improvement of public facilities on a small scale and environmental and residential improvement, Honor village fund implementation team and strengthening village institutions and other village activities that are considered important.

While the use of Village Funds for the implementation of village government is directed to support the implementation of village government and the operation of village consultative bodies. This is under the contents of regulation of the Minister of Home Affairs (Minister of 
Home Affairs) No. 113 of 2014 in Chapter 2 of Article 2, which states that village finances are managed based on transparent, accountable, participative principles of fiber conducted in an orderly and disciplined budget. As referred to in paragraph (1), the financial management of village funds is managed within 1 (1) fiscal year, starting from January 1 to December 31.

\section{Table 1}

Receipt of village funds from Gowa Regency in 2018-2019

\begin{tabular}{|c|c|c|}
\hline No. & Budget Year & Village Fund Total (IDR) \\
\hline 1 & 2018 & $1,056,499,761$ \\
\hline 2 & 2019 & $2,175,866,062$ \\
\hline \multicolumn{2}{|c|}{ Total } & $3,232,365,821$ \\
\hline
\end{tabular}

Source: Community Empowerment Office of Gowa Regency.

Based on the table above from the Gowa Village Community Empowerment Office conducted in September 2019 shows that the amount of village fund receipts in 2018-2019 in Sunggumanai, Gowa Regency in each year has increased the amount of budget so that the allocation of funds is expected to provide improved infrastructure development, human resource development and improve the welfare of the community. Therefore, the village government must provide access to information that is easy to reach, freely obtained on time to the community related to the use of village funds. It affects community participation in regional development.

To avoid cheating during the DD management process, all layers ranging from authorized officials to the public must know the concept of transparency so that there is no apathy in carrying out everything from planning, management to accountability.

The transparency of the use of village funds is still considered a threat to some public officials. Some information related to using village funds is often only controlled by a handful of elites. The disclosure of such information and policies is primarily related to financial use. Village funds are considered sensitive when faced with the obligation of the village government to meet the aspects of transparency.

Based on online media coverage on May 17, 2019, published by liputan6.com, Gowa police have established two suspects in constructing a dream city in the Pattalassang district of Gowa, South Sulawesi. The investigation conducted by Gowa police only focuses on proving the alleged crime of falsifying some documents connected with the land that is a state asset in this case belonging to PT.

Based on the data and empirical facts presented, it attracted the attention of researchers to explore in-depth the use of village funds, so that the title of this study is "Transparency of Village Fund Management in Sunggumanai Village, Gowa Regency?.".

\section{METHOD}

The type of research used in this study is qualitative research. Denzin and Licon (in Sugiyono 4: 2011) define qualitative research as research that uses the natural background to interpret phenomena that occur and are done using involving various methods. Various characteristics that have, qualitative research has its uniqueness, so it is different from quantitative research.

The location of this research was conducted in the village of Sunggumanai, Pattallassang district, Gowa regency. The object of the study is the community and the village government, especially in the village government involved in managing village funds and village consultative 
bodies (BPD) as community representative institutions that supervise the performance of the village government.

This research uses a qualitative research method with a phenomenological approach. The use of this method because the focus in this study is Transparency of Management and Village. In comparison, the phenomenological approach aims to describe the meaning of life experiences experienced by some individuals, about certain concepts or phenomena, by exploring the structure of human consciousness so here researchers want to know the importance of the experience or observations experienced by the villagers Sunggumanai related to the transparency of village fund management.

"According to (Creswell \& Clark, 2017; Creswell \& Creswell, 2017)said that informants should meet the following criteria: Those who master and understand something through the process of enculturation so that something is not just known but lived".

\section{Data Collection Techniques}

\section{Observation}

Observation is a way of collecting data by conducting observation activities directly on research objects by not participating in the work process but remain focused on events, symptoms, or something based on facts that occur directly in the field and then record the behavior and events as they occur in the actual circumstances.

\section{Interview}

Interviews are a way of obtaining information and collecting data through informants who know a lot about the problems that researchers will review. Interview activities will be conducted in-depth interviews by asking questions in an open format, listening and recording the answers obtained then the results of the interview results are made in the form of hard copy.

\section{Documentation}

In this case, the documentation referred to is in the form of documents, photos, or videos taken during the implementation of the research and used as an amplifier of the research results that this research is carried out.

\section{Data validity}

Data validity testing is conducted to test the credibility of the data or trust in the data of the research results, which is done by two techniques:

\section{Triangulation}

Triangulation is defined as a test of the validity of data obtained from the results of data collection that have been analyzed. Triangulation is done by checking the correctness of data or information on other sources by reducing some differences at the time of data collection and analysis to obtain a high level of truth.

The data obtained is further viewed as the suitability of the information provided. Furthermore, information that is considered the same and relevant from the informants will be chosen to be concluded.

\section{Member Check}

Member check is the process of checking the data obtained at other sources to know the suitability or accuracy of the data found with the data provided by the data source. Member check is done after the data collection process is complete or after obtaining the conclusion. 


\section{Data Analysis Techniques}

In scientific research, data analysis is a crucial step because there is a process of systematically finding and compiling data obtained from the research results in the field. To easily understand and get more objective conclusions from the research, the data collected during the study will be grouped into several categories, sorting out important, and analyzed and interpreted in detail, thoroughly and carefully.

\section{Data Reduction}

Previously obtained data (observations, interviews, and documentation) are collected and then reduced to provide a more specific picture and make it easier for researchers to draw conclusions that can be described and verified. The process of reducing data begins by sorting the data from the written records in the field during the analysis.

\section{Data Presentation}

Data presentation is a data model that collects information from the results of data reduction that has been arranged in an interconnected pattern, so it is easy to understand. The presentation of this data is done in the form of the narrative text so that researchers can analyze it according to the purpose. In this step, the researchers looked at which relevant data on Transparency of Village Fund Management in Sunggumanai Village, Gowa Regency, the data was compiled into information that allows the decryption of conclusions.

\section{Summarizing}

The final stage is the summary or verification. The summary is made carefully by reviewing the data collected at the time of research and then verified, processed, and systematically compiled to draw a proven conclusion to support the truth of the research and tested.

\section{RESULT AND DISCUSSION}

\section{Availability of adequate information about village funds.}

Adequate information becomes one of the important aspects in improving village development. Therefore, the village government plays an active role in ensuring the disclosure of information related to village funds to the community. The information provided to the community is actual and accurate information, not fictitious information to abort the village government's responsibility. With adequate information, Sunggumanai villagers can supervise every village development activity that have been planned together as outlined in the Village Medium Term Development Plan (RPJMDesa) and Village Development Work Plan (RKP Desa).

Disclosure of information becomes the obligation of the Sunggumanai village government as a responsibility for the management of the village government, especially the use of village funds. The obligation to carry out information disclosure is regulated by Law No. 14/2008 on Public Information Disclosure (KIP Law) and ministerial regulation no. 6 of 2018 on Public Information Services and Community Complaints in the Ministry of Villages, Development of Disadvantaged Regions, and Transmigration.

The results of the search conducted by the author related to the availability of adequate information in Sunggumanai Village that the Sunggumanai Village government has made efforts in providing the information needed by the community related to the transparency of the 
use of Village Funds, among others, the installation of information boards in the form of banners on the use of Village Funds in general. In addition, the installation of information boards on the use of Village Funds for each physical activity and community development has also been carried out by the Sunggumanai Village government at this time.

\section{Community Knowledge about the implementation of local government}

Community knowledge about village funds is one of the benchmarks for the success of the village government in applying the principle of transparency. All village communities can know all village government activities related to village funds. In this case, the community knows about village funds, namely where the community is always aware of the Village Government's various physical and non-physical development programs and how much village funds are received. The villagers obtained various information that was able to improve the knowledge of the community and are expected to be able to participate in various programs that the Sunggumanai Village Government will implement.

The level of knowledge of the people of Sunggumanai village that is assessed by the people there is quite aware of all the allocation of village budget funds allocated for the development of Sunggumanai village. The form of giving understanding conducted by the Sunggumanai village government in the form of information delivery through meetings with village heads and local community leaders and also carried out in the form of information delivery through the bulletin board in the village office about the design of village activities programs along with budgets allocated for activities.

\section{Increasing Public Trust in Village Fund Management}

Creating a good government, especially in the village government, needs to pay attention to the level of community trust to run the organization's wheels effectively. The village government has a closer relationship with the community looking at the structure of the village government that is in direct contact with the community. This is what makes a difference to the central government and the village government.

Increasing public trust in the village government in managing the Village Fund can allow the government to run the government. The efforts of the Sunggumanai village government in increasing the trust of the village community have been able to be carried out properly because with the government's efforts in empowering the village community, Sunggumanai increase the trust of the community that can be seen from the participation of the community in the village program both physical and non-physical.

Sunggumanai village government has good ability in increasing public trust in the village government, and it is an improvement in running the wheels of government in Sunggumanai Village. It is also able to increase effectiveness and efficiency in running every village program that has been planned. With the government's efforts that focus on information disclosure, including the transparency of village funds, the government provides opportunities for the community to understand the administration better; of course, it aims to give the community confidence.

\section{Increasing Community Participation in Village Fund Activities.}

Participation becomes a much-needed thing in running a good government. One of the things that improve the village's development is the community's participation, especially the villagers. People who have an awareness of the importance of village development will always 
strive to realize the wishes of the village government in developing their village. Therefore, the government must take a quick step in seeking to increase community participation.

The Sunggumanai village government has made efforts to realize the principle of transparency about community participation. The increasing involvement of the community will be in line with the implementation of village development that increases and achieved a good village governance system. The community in Sunggumanai Village has participated well in all developments carried out by the village government. This is evident from the participation of the community by engaging in deliberation activities that discuss the design of village development activities programs and involvement in the implementation stage of development.

Community participation in village government development activities can also be indicated that the Sunggumanai village government is successful enough to protect and include the community, and this is a participatory form carried out by the Sunggumanai village government in carrying out its governance duties.

\section{CONCLUSION}

Based on the research results that have been presented above, it can be concluded about the Transparency of Village Fund Management in Sunggumanai Village, Gowa Regency, with a focus on transparency of village fund management and the availability of adequate information. Judging from the availability of adequate information is good enough, the knowledge of the community about the implementation of village government against considered good enough, the increasing partisanism of the community in the development is quite good, and the increasing participation of the community in development is good enough as well, so that overall see the transparency of the use of village funds in the village of Sunggumanai Pattalassang Subdistrict Gowa has been running quite well.

\section{REFERENCES}

Creswell, J. W., \& Clark, V. L. P. (2017). Designing and conducting mixed methods research. Sage publications.

Creswell, J. W., \& Creswell, J. D. (2017). Research design: Qualitative, quantitative, and mixed methods approaches. Sage publications.

Daraba, D., Guntur, M., Kartini, F., \& Salam, R. (2018). The Impact of Village Expansion Policy on Public Service Aspects at Sadar Village Bone-Bone District of North Luwu Regency. Colloquium, 50.

Handoyo, E. (2012). Kebijakan Publik. Kebijakan Publik Deliberatif, 9.

Inskeep, E. (1991). Tourism planning: an integrated and sustainable development approach. Van Nostrand Reinhold.

Isma, E. W., Darwis, M., Saleh, S., \& Salam, R. (2017). Kualitas Pelayanan Administrasi pada Puskesmas Gattareng Kecamatan Gantarang Kabupaten Bulukumba. JURNAL ILMU ADMINISTRASI PERKANTORAN (JIAP), 21-28.

Kahar, F., Asse, A., Nasrullah, M., Akib, H., \& Saslam, R. (2019). Role of Village Head as Development Administrator in Mattirowalie Village Maniangpajo subdistrict Wajo District. International Conference on Social Science 2019 (ICSS 2019).

Marcellus, I. O. (2009). Development planning in nigeria: reflections on the national economic empowerment and development strategy (NEEDS) 2003-2007. Journal of social sciences, 20(3), 197-210.

Niswaty, R., Nasrullah, M., Akib, H., \& Salam, R. (2020). Sistem Pelayanan Pembentukan Koperasi di Dinas Koperasi dan UKM Kota Makassar. Journal of Public Administration 
and Government, 2(1), 14-18.

Nugroho, S., Bandono, A., \& Suharyo, O. (2021). Human resources development assessment planning program and bureaucratic reform management on the performance of government organization. Management Science Letters, 11(4), 1429-1438. https://doi.org/10.5267/j.msl.2020.10.020

Saggaf, S., Salam, R., Kahar, F., \& Akib, H. (2014). Pelayanan Fungsi Administrasi Perkantoran Modern. Jurnal Ad'ministrare, 1(1), 20-27.

Salam, R. (2015). Pelayanan Fungsi Administrasi Perkantoran Modern Sebagai Basis Persaingan Masyarakat Ekonomi Asean (MEA) 2015. Seminar Nasional Dies Natalis UNM ke-54 "Peran Pendidikan Karakter Melalui Optimalisasi IPTEK Pencerdasan Generasi Unggul. 